Short communication

\title{
Determination of milk production losses and variations of fat and protein percentages according to different levels of somatic cell count in Valle del Belice dairy sheep
}

\author{
Anna Maria Sutera*, Baldassare Portolano, Rosalia Di Gerlando, Maria Teresa Sardina, \\ Salvatore Mastrangelo, Marco Tolone \\ Dipartimento Scienze Agrarie e Forestali, Università degli Studi di Palermo, Viale delle Scienze, 90128, Palermo, Italy
}

\section{A R T I C L E I N F O}

\section{Keywords:}

Valle del Belice sheep

Mastitis

Somatic cell count

Milk production traits

\begin{abstract}
A B S T R A C T
The somatic cell count (SCC) of milk is widely used to monitor udder health and the milk quality and because of its positive genetic correlation with mastitis this trait was included in breeding schemes of dairy sheep. The aim of this study was to estimate the loss in milk yield (MY) and related composition resulting from different levels of somatic cell count in Valle del Belice dairy sheep. Data were collected between 2006 and 2016 in 15 flocks following an A4 recording scheme. Somatic cell count (SCC), fat and protein percentage (F\% and P\%) were determined using mid-infrared spectroscopy. To evaluate loss in test day MY, F\% and P\%, five different classes of SCC were arbitrarily defined: SCC1 $\leq 500 \times 10^{3}, \quad 500 \times 10^{3}<$ SCC2 $\leq 1000 \times 10^{3}$, $1000 \times 10^{3}<$ SCC3 $\leq 1500 \times 10^{3}, 1500 \times 10^{3}<$ SCC4 $\leq 2000 \times 10^{3}$ and SCC5 $>2000 \times 10^{3}$. To estimate the loss of milk production and quality a linear model, with test day milk production traits as dependent variable, was used. Furthermore, the effect of order of parity and season of lambing were investigated to study the effects on milk production traits. Least squares means were computed for milk production traits and the differences between means were determined by Fischer's least significant difference. The estimated losses in MY according to the level of used SCC were approximately $16 \%$ whereas there was an increase of $0.06 \%$ and $0.29 \%$ for fat and protein percentage, respectively. Apart from environmental factors and management, this study confirms that high levels of somatic cell count in sheep milk are associated with milk yield losses and changes in milk composition. Results suggest that it is necessary to implement a program aimed to reduce the milk somatic cell count in ewes' milk, with the aim of improving the quality of ewes' milk and dairy products.
\end{abstract}

\section{Introduction}

The major income from dairy animals is derived from milk therefore factors that reduce milk quantity and quality can cause high economic losses to the farmers. Sheep milk production accounts for $4.6 \%$ of the total milk production in Italy (ISTAT, 2016) and the Mediterranean basin with $60 \%$ of total world production is the most important area . Mastitis is an inflammation of the udder, generally caused by bacteria and it is the most prevalent disease present in dairy livestock species that, in addition to altering the state of well-being and health of the animals, it leads to economic loss mainly due to loss of milk during lactation, veterinary treatments, lower longevity and involuntary culling (Tolone et al., 2013a). Udder infection in dairy sheep has negative effects both on the yield and quality of milk (Gonzalo et al., 2006) with economic losses greater than those reported for dairy cattle (Halasa et al., 2009). Mammary infections also cause high somatic cell count
(SCC) (Ariznabarreta et al., 2002; Pengov, 2001), and result in important losses of curd and cheese yields (Leitner et al., 2008; RaynalLjutovac et al., 2007). Therefore, mastitis, in addition to being a problem in animal welfare, is a food quality and safety problem. Selecting for increased genetic resistance to mastitis can be done directly or indirectly. Direct bacteriological assay is considered to be the most reliable method of diagnosis of mastitis in sheep, because it provides information on both the infected quarters and the involved pathogens. However, it is difficult to implement on a large scale because it is expensive, slow and requires significant laboratory support (McDougall et al., 2001). Among the indirect methods, the most frequently used to detect mastitis are the California Mastitis Test (CMT) and electrical impedance. These methods are indicators of the SCC of milk. The SCC of milk is widely used to monitor udder health and milk quality and it was included in the breeding schemes of dairy sheep such as for the Lacaune breed in France (Barillet, 2007). The measure of SCC has the following

\footnotetext{
* Corresponding author.

E-mail address: annamaria.sutera01@unipa.it (A.M. Sutera).
} 
properties: it can be routinely recorded in most milk recording systems and it is an indicator of both clinical and subclinical infections. Research documenting distinct physiological differences in the process of milk secretion between cows, sheep and goats establishes a lack of justification for applying cow milk regulatory standards to small ruminant milk, specifically using SCC. Whereas in cattle SCC values between $250 \times 10^{3}$ and $300 \times 10^{3}$ cells $/ \mathrm{mL}$ are recommended as most satisfactory discrimination thresholds between healthy and infected udders (Leitner et al., 2008), in sheep there is no universally accepted threshold. To determine a SCC threshold value in order to discriminate between healthy and infected animals would be of crucial importance both for consumer's safety and for small ruminants breeding system. Mastitis-control costs are a priori known or easy to estimate, whereas losses due to different levels of SCC are more difficult to evaluate accurately. Therefore, an appropriate evaluation of SCC effect on MY is needed because the decrease in milk production is considered the main component of the economic losses. The aim of this study was to estimate losses in $\mathrm{MY}$, and variation of $\mathrm{F} \%$ and $\mathrm{P} \%$ according to different levels of SCC in Valle del Belice dairy sheep. These results could be used as basic input in estimation of SCC economic value to implement a selection index that includes SCC as trait.

\section{Materials and methods}

Phenotypic data were collected by the University of Palermo between 2006 and 2016 in 15 Valle del Belice flocks. The procedures involving animal sample collection followed the recommendation of directive 2010/63/EU. Milk samples were collected at approximately monthly intervals following an A4 recording scheme (ICAR, 2014). All ewes were milked manually twice a day and milk from both milking was collected, stored at $4{ }^{\circ} \mathrm{C}$ and transferred to the laboratory, to determine daily MY, F\%, P\% and SCC. Within $48 \mathrm{~h}$ from samples collection, milk composition was determined by the method of infrared spectrophotometry using Combifoss 6200 (Foss Electric Hillerød, Denmark) equipment. The original data set used for this study included 92,261 records of 6763 ewes. Data editing was performed using S.A.S. version 9.2 (SAS, Institute Inc., 2010) to guarantee the quality of the data to be analyzed. All test-day records used in the analysis were required to have information regarding MY, F\%, P\% and SCC. Animals with less than 3 test-day measurements within lactation were discarded. After editing, the data set consisted of 17,060 observations of 2418 ewes. Five stages of lactation were determined according to days in milk (DIM) as follows: 1: DIM $\leq 60 ; 2$ : $60<\mathrm{DIM} \leq 120 ; 3$ : $120<\mathrm{DIM} \leq 180 ; 4: 180<\mathrm{DIM} \leq 270$ and 5 : DIM $>270$. Season of lambing (SOL) was classified in three classes: 1 if the lambing was from August to November; 2 from December to March; 3 from April to July. To evaluate loss in test day MY, F\% and P\%, five different classes of SCC were arbitrarily defined: SCC1 $\leq 500 \times 10^{3}$; $500 \times 10^{3}<$ SCC2 $\leq 1000 \times 10^{3}$;

$1000 \times 10^{3}<$ SCC $3 \leq 1500 \times 10^{3}$;

$1500 \times 10^{3}<$ SCC $4 \leq 2000 \times 10^{3}$ and SCC5 $>2000 \times 10^{3}$ cells $/ \mathrm{ml}$. To estimate the loss of MY, $\mathrm{P} \%$ and $\mathrm{F} \%$ according to different levels of SCC, a linear model was used with the GLM procedure of the S.A.S. version 9.2 (SAS, Institute Inc., 2010). In particular, the following model was used for MY and P\%:

$y_{i j k l m}=\mu+F Y S_{i}+O P_{j}+\beta(\mathrm{AOP})_{i j k l}+S C C_{k}+D I M_{l}+e_{i j k l m}$

$y_{i j k l m}=\mu+F Y S_{i}+O P_{j}+\beta(\mathrm{AOP})_{i j k l}+S C C_{k}+M Y_{l}\left(\mathrm{FLOCK}{ }^{*} \mathrm{DIM}\right)+e_{i j-}$ $\mathrm{klm}$

where $\mathrm{y}_{\mathrm{ijklm}}$ is the $\mathrm{ijklm}{ }^{\text {th }}$ observations vector for MY, $\mathrm{P} \%$ or $\mathrm{F} \%$ test day as weighted mean of morning and evening milk production; $\mu$ is the population mean; $F Y S_{i}$ is the random effect of flock by year of parity and season; $\mathrm{OP}_{\mathrm{j}}$ is the fixed effect of parity class $\mathrm{j}$ (4 levels); (AOP) $)_{\mathrm{ijklm}}$ is the age of lambing as covariate; SCC $_{k}$ is the fixed effect of SCC levels 1 ( 5 levels); $\mathrm{DIM}_{1}$ is the fixed effect of days in milk $\mathrm{m}$ (5 levels) and $\mathrm{e}_{\mathrm{ijklm}}$ is
Table 1

Descriptive statistics of test-day milk yield (MY, g), somatic cell count (SCC $\times 10^{3}$ ), fat (F $\%)$ and protein (P\%) percentages in Valle del Belice sheep breed.

\begin{tabular}{lllll}
\hline Daily measurements & $\mathrm{N}$ & Mean $\pm \mathrm{SD}$ & Min & Max \\
\hline MY $(\mathrm{g})$ & 17,060 & $1135 \pm 603$ & 56 & 4300 \\
$\mathrm{SCC} \times 10^{3}$ & 17,060 & $1544 \pm 3547$ & 5 & 29,368 \\
F\% & 17,060 & $7.25 \pm 1.23$ & 2.33 & 14.56 \\
P\% & 17,060 & $5.80 \pm 0.72$ & 3.46 & 13.90 \\
\hline
\end{tabular}

SD: standard deviation.

the random error. In the second model $M Y_{l}($ FLOCK*DIM) interaction was used to adjust F\% for milk production within flock and stage of lactation. Furthermore, the effect of OP and SOL were investigated to study the relation between parity and season of lambing with milk production traits including all the observations. Least squares means (LSM) were computed for MY, F\% and P\% and the differences between means were determined by Fischer's least significant difference.

\section{Results}

The descriptive statistics for milk production traits were reported in Table 1. All fixed effects, for MY and P\% included in the first model were highly significant $(\mathrm{P}<0.001)$. Table 2 showed the losses for MY, F\% and P\% due to different levels of SOL and OP fixed effects. The effect of losses in MY, and variation of $\mathrm{F} \%$ and $\mathrm{P} \%$ according to different levels of SCC were reported in Table 3. The estimated losses in MY were approximately $16 \%$ and ranged from $1052 \mathrm{~g}$ for SCC1 to $883 \mathrm{~g}$ for SCC5 (Table 3). The Fig. 1a reported that milk production for SCC1 was statistically different for milk production of each SCC class. It should be noted that according to the different levels used for SCC, an inverse effect on milk yield was observed (Table 3). Table 3 showed the least square means for F\% depending on SCC class. The F\% increased from $7.39 \%$ to $7.47 \%$ corresponding to an increase of around $0.06 \%$. The F\% for the SCC1 class was statistically different only from F\% of SCC5 class (Fig. 1b). The least-squares means for P\% depending on SCC class were reported in Table 3. Protein percentage increased from $5.69 \%$ to $5.98 \%$ corresponding to an increase of $0.29 \%$ of protein concentration in milk. The Fig. 1c showed that P\% for SCC1 was statistically different for $\mathrm{P} \%$ of each SCC class. It should be noted that according to the different classes used for SCC, a continuous increase on P\% was observed (Table 3 ).

\section{Discussion}

In the present study the milk production losses and variation of $\mathrm{F} \%$ and $\mathrm{P} \%$ according to different levels of SCC in Valle del Belice dairy sheep were investigated.

The means for MY, F\% and P\% were similar to those reported by Tolone et al. (2013a, 2013b) while the mean SCC was higher than the value obtained by the same authors for the Valle del Belice sheep breed (Tolone et al., 2013b). Ewes lambed from August to November (SOL 1) produced more milk than those lambed from December to March (SOL

Table 2

Effects of parity (OP) and season of lambing (SOL) on milk yield (MY, g), fat (F\%) and protein $(\mathrm{P} \%)$ percentages in Valle del Belice sheep breed.

\begin{tabular}{lllll}
\hline & Levels & MY $(\mathrm{g})$ & $\mathrm{F} \%$ & $\mathrm{P} \%$ \\
\hline \multirow{2}{*}{ SOL } & 1 & 0.000 & 0.000 & 0.000 \\
& 2 & -180.4 & -0.030 & -0.06 \\
& 3 & -166.7 & 0.12 & -0.13 \\
OP & 1 & -52.78 & 0.11 & 0.02 \\
& 2 & 0.000 & 0.000 & 0.000 \\
& 3 & -80.09 & 0.11 & 0.06 \\
& 4 & -6.16 & 0.21 & 0.13 \\
\hline
\end{tabular}


Table 3

Least square means for test-day milk yield (MY, g), fat (F\%) and protein (P\%) percentages, according to different class of somatic cell count (SCC) in Valle del Belice sheep. SCC (cells/ml) ranges within brackets.

\begin{tabular}{|c|c|c|c|}
\hline SCC & $\operatorname{MY}(g)$ & $\mathrm{F} \%$ & $\mathrm{P} \%$ \\
\hline $\operatorname{SCC} 1{ }_{(\operatorname{SCC} 1 \leq 500 \times 10)^{3}}$ & $1,052.49^{\mathrm{a}}$ & $7.39^{\mathrm{a}}$ & $5.69^{\mathrm{a}}$ \\
\hline $\operatorname{SCC} 2(500<\operatorname{SCC} 2 \leq 1000 \times 10)^{3}$ & $950.69^{\mathrm{b}}$ & 7.44 & $5.80^{\mathrm{b}}$ \\
\hline SCC $3(1000<\operatorname{SCC} 3 \leq 1500 \times 10)^{3}$ & $930.79^{c}$ & 7.42 & $5.86^{\mathrm{c}}$ \\
\hline SCC $4(1500<\operatorname{SCC} 5 \leq 2000 \times 10)^{3}$ & $917.64^{\mathrm{d}}$ & 7.47 & $5.93^{\mathrm{d}}$ \\
\hline SCC5 $(\text { SCC5 }>2000 \times 10)^{3}$ & $883.43^{\mathrm{e}}$ & $7.45^{\mathrm{b}}$ & $5.98^{\mathrm{e}}$ \\
\hline
\end{tabular}

Values within the same trait with different superscript letters are significantly different at $\mathrm{p}<0.01$.

2) $(-180 \mathrm{~g} /$ day) and from April to July (SOL 3) ( $-166 \mathrm{~g} /$ day). This was probably caused by the inadequate production of pasture as a result of low rainfall in this period to the fact that long term draughts and high temperature lead a drop in milk yield. Ewes lambed from April to July showed slightly higher F\% and slightly lower P\% compared to the other seasons of lambing $(+0.12 \%$ and $-0.13 \%$, respectively). Considering the OP effect, ewes at second lambing were more productive (MY) than primiparous and ewes with higher order of parity, whereas for F\% and P\% showed lower values. A similar trend for MY was reported by Reiad et al. (2010) in Awassi sheep. This is interpreted as the effect of maturity with advancing age of parity. Results showed that SOL and OP affected quantitative and qualitative traits.

Our results were similar to those reported in previous studies, in which several authors have indicated a relationship between an increase in SCC and a decrease in milk yield. Olechnowicz et al. (2010) found that SCC in milk from one or both halves of udders exceeding $250 \times 10^{3}$ cells $/ \mathrm{mL}$, resulted in a statistically significant $(\mathrm{p}<0.01)$ decrease in daily milk production of ewes, approximately of $15.89 \%$ and $30.22 \%$, respectively. Leitner et al. (2008) suggested that infection of 25,50 and $75 \%$ of udders was associated with $4.1-12.2 \%$ of milk loss in sheep, and $0.8-2.3 \%$ in goats. Moreover, milk yield loss varies according to the causative pathogen and to unilateral or bilateral character of mastitis and ranges from $3 \%$ to $10 \%$, as reported by Gonzalo et al. (2002) for the Churra sheep breed. Even during subclinical mastitis, milk yield of the infected halves $(0.36 \mathrm{~kg} / \mathrm{milking})$ significantly decreases in comparison to milk yield of the uninfected halves $(0.76 \mathrm{~kg} /$ milking) (Leitner et al., 2004) and these changes were associated with increases in plasmin activity, indices of inflammation, proteolysis of casein and a decrease in lactose concentration (Silanikove et al., 2006). In addition, sheep showed the highest relative increase in PMN (polymorphonuclear neutrophils) proportion, one of the main cell type of SCC, in response to subclinical mastitis, five times the relative increase observed in cow and goat and these differences may evolve from a larger decrease in milk secretion in the infected glands (Leitner et al., 2012).

Several authors reported that SCC did not affect F\% of ewes' milk (Pirisi et al., 2000) or goats' milk (Ying et al., 2002). In contrast with our results, Bianchi et al. (2004) observed a significant decrease of F\% in milk of infected Sarda ewes from $7.06 \%$ to $6.16 \%$. Another study, conducted in three dairy goat breeds, reported loss of $\mathrm{F} \%$ related with different levels of SCC (Barrón-Bravo et al., 2013). This can be expected due to a reduced synthetic and secretory capacity of the mammary gland (Auldist and Hubble, 1998; Raynal-Ljutovac et al., 2007). A rise in free fatty acids has been reported in mastitic cows' milk. This may be explained by the alteration of the milk fat globule membrane by leucocyte lipases or by plasmin through the hydrolysis of lipoproteins, both of which may enhance lipolysis (Le Maréchal et al., 2011). Nevertheless, results regarding lipoprotein lipase activity in mastitic milk are also contradictory; in fact, some authors found that its activity increased during mastitis, others reported that it decreased or found no significant differences (Le Maréchal et al., 2011). In a study of Leitner et al. (2007), fat concentration was not affected by bacteriological status although the method used by these authors considered the infection at udder level and not as in our case at animal level. Altogether these results appear somehow conflicting and it is difficult or impossible to draw a clear conclusion upon the impact of high SCC on fat composition.

For the effect of SCC class on P\% our result was in agreement with a previous study, where the authors reported a positive phenotypic correlation between SCC and P\% in the Valle del Belice dairy ewes (Riggio et al., 2007). However, the possible increase in $\mathrm{P} \%$ has to be examined critically, since studies on the effects of SCC on P\% in sheep milk are numerous and sometimes conflicting. Increases in the concentration of proteins from blood during mastitis leads to an increase in the concentration of soluble whey proteins as serumalbumin, immunoglobulins and PMN (Albenzio et al., 2004; Nudda et al., 2003). Several authors reported that sheep milk with a high SCC contains more total protein than milk with low SCC (Albenzio et al., 2004; Bianchi et al., 2004). On the contrary, Jaeggi et al. (2003) found total protein content was lowest in milk with the highest SCC levels. In a review, Le Maréchal et al. (2011) reported that in general there is an increase in the concentration of protein compounds associated with the inflammatory and immune response and a decrease in endogenous milk protein such as caseins. Bianchi et al. (2004) found a decrease of casein index percentage (ratio of casein to crude protein) in infected Sarda dairy sheep compared to healthy ewes. In a study conducted by Barrón-Bravo et al. (2013) reported different loss of $\mathrm{P} \%$ in three dairy goat breed related to SCC levels. The reduction in casein content was also reported in dairy cows where intramammary infections generated a significant reduction in
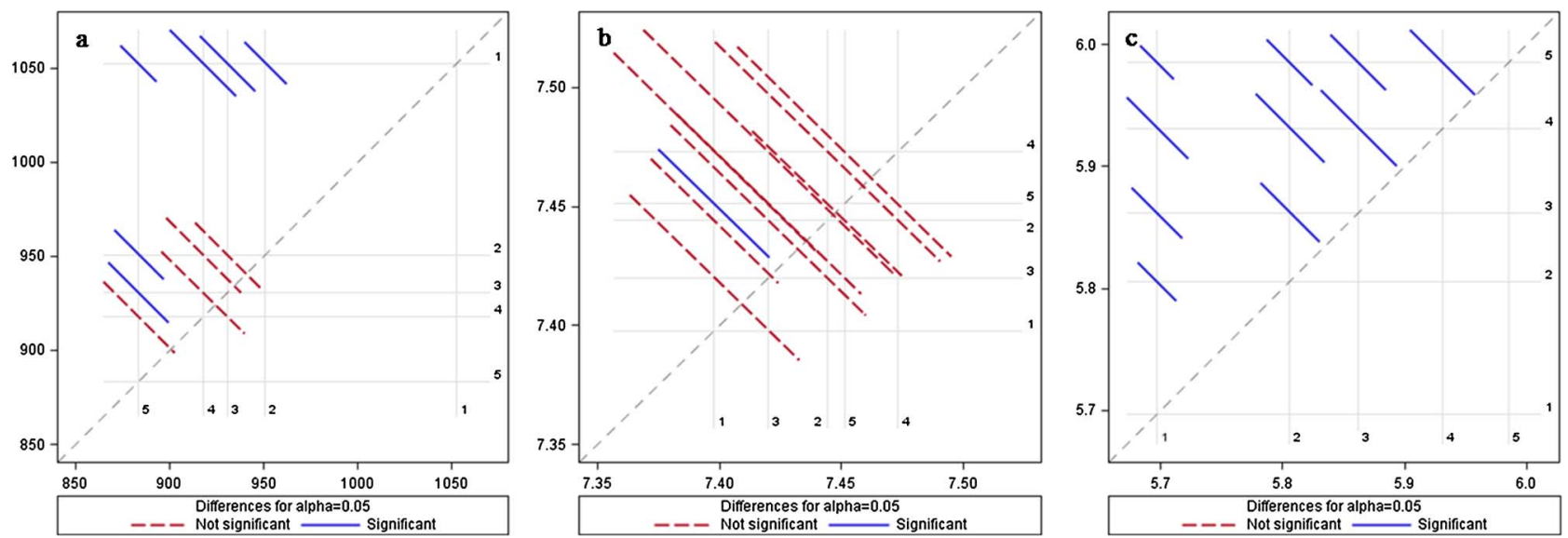

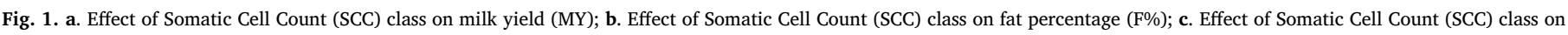
protein percentage $(\mathrm{P} \%)$. 
casein synthesis (Hortet and Seegers, 1998) due to the increase of blood elements more than compensates for the effects of the reduction of casein secretion. Moreover, in dairy cows an irreversible damage to casein micelles that impede subsequent curd formation due to the immune response to invading bacteria, elevation of plasmin and other proteolytic enzymes was reported (Silanikove et al., 2010). The casein content of the sheep milk is the most important protein fraction and the manufacturers of dairy products report problems in processing milk with poor casein content (Li et al., 2014).

The presented results indicate that the dairy industry may have underestimated the economic impact of SCC on ewes' dairy products and breeders should aim to reduce the number of somatic cells in milk both with proper management and genetic selection. Applying SCC measurements as a routine management tool is highly recommended because it should help in defining milk quality, preventing food toxicity and searching for strategies to improve milk yield and quality (Silanikove et al., 2010).

\section{Conclusion}

In the present study, SCC levels were estimated to evaluate their role in milk yield and quality. This study confirms that high levels of SCC in sheep milk are associated with milk yield losses and changes in milk composition. The literature is quite abundant regarding these observed impacts but, nevertheless, the reported observations sometimes appear contradictory. This research suggests that there could be a possible alteration of milk quality also below $500 \times 10^{3} \mathrm{cells} / \mathrm{ml}$. The estimated losses in MY according to the used levels of SCC were approximately $16 \%$, whereas there was an increase of $0.06 \%$ and $0.29 \%$ for $\mathrm{F} \%$ and $\mathrm{P}$ $\%$, respectively. These experimental results, finally, together with data present in the literature, demonstrated that it is necessary to implement a program aimed to reduce the milk somatic cell count in ewes' milk, with the aim of improving the quality of ewes' milk and dairy products. Moreover, these results could be used to quantify the economic loss due to an increase in somatic cell count that is crucial to estimate the economic value for SCC trait in Valle del Belice dairy sheep.

\section{Conflict of interests}

The authors declare that they have no conflict of interests.

\section{References}

Albenzio, M., Caroprese, M., Santillo, A., Marino, R., Taibi, L., Sevi, A., 2004. Effects of somatic cell count and stage of lactation on the plasmin activity and cheese-making properties of ewe milk. J. Dairy Sci. 87, 533-542.

Ariznabarreta, A., Gonzalo, C., San Primitivo, F., 2002. Microbiological quality and somatic cell count of ewe milk with special reference to staphylococci. J. Dairy Sci. 85, $1370-1375$.

Auldist, M.J., Hubble, I.B., 1998. Effects of mastitis on raw milk and dairy products. Aust. J. Dairy Technol. 53, 28-36.

Barillet, F., 2007. Genetic improvement for dairy production in sheep and goats. Small Rumin. Res. 70, 60-75.

Barrón-Bravo, O.G., Gutiérrez-Chávez, A.J., Ángel-Sahagún, C.A., Montaldo, H.H., Shepard, L., Valencia-Posadas, M., 2013. Losses in milk yield, fat and protein contents according to different levels of somatic cell count in dairy goats. Small Rumin. Res. $113,421-431$.

Bianchi, L., Bolla, A., Budelli, E., Caroli, A., Casoli, C., Pauselli, M., Duranti, E., 2004. Effect of udder health status and lactation phase on the characteristics of Sardinian ewe milk. J. Dairy Sci. 87, 2401-2408.

Gonzalo, C., Ariznabarreta, A., Carriedo, J.A., San Primitivo, F., 2002. Mammary pathogens and their relationship to somatic cell count and milk yield losses in dairy ewes. J. Dairy Sci. 85, 1460-1467.

Gonzalo, C., Carriedo, J.A., Beneitez, E., Juárez, M.T., De La Fuente, L.F., San Primitivo, F., 2006. Short communication: bulk tank total bacterial count in dairy sheep: factors of variation and relationship with somatic cell count. J. Dairy Sci. 89, 549-552.

Halasa, T., Nielen, M., De Roos, A.P.W., Van Hoorne, R., de Jong, G., Lam, T.J.G.M., van Werven, T., Hogeveen, H., 2009. Production loss due to new subclinical mastitis in Dutch dairy cows estimated with a test-day model. J. Dairy Sci. 92, 599-606.

Hortet, P., Seegers, H., 1998. Loss in milk yield and related composition changes resulting from clinical mastitis in dairy cows. Prev. Vet. Med. 37, 1-20.

ICAR. International Committee for Animal Recording, International Agreement of Recording Practices. Available online: http://www.icar.org/documents/Rules \%20and\%20regulations/Guidelines/Guidelines_2012. (Accessed 26 December 2014).

ISTAT, 2016. Annuario Statistico Italiano. Istituto Nazionale di statistica.

Jaeggi, J.J., Govindasamy-Lucey, S., Berger, Y.M., Johnson, M.E., McKusick, B.C., Thomas, D.L., Wendorff, W.L., 2003. Hard ewe's milk cheese manufactured from milk of three different groups of somatic cell counts. J. Dairy Sci. 86, 3082-3089.

Le Maréchal, C., Thiéry, R., Vautor, E., Le Loir, Y., 2011. Mastitis impact on technological properties of milk and quality of milk products-A review. Dairy Sci. Technol. 91, $247-282$.

Leitner, G., Chaffer, M., Shamay, A., Shapiro, F., Merin, U., Ezra, E., Saran, A., Silanikove, N., 2004. Changes in milk composition as affected by subclinical mastitis in sheep. J. Dairy Sci. 87, 46-52.

Leitner, G., Merin, U., Lavi, U., Egber, A., Silanikove, N., 2007. Aetiology of intramammary infection and its effect on milk composition in goat flocks. J. Dairy Res. 74, 186-193.

Leitner, G., Silanikove, N., Merin, U., 2008. Estimate of milk and curd yield loss of sheep and goats with intrammamary infection and its relation to somatic cell count. Small Rumin. Res. 74, 221-225.

Leitner, G., Merin, U., Krifucks, O., Blum, S., Rivas, A.L., Silanikove, N., 2012. Effects of intra-mammary bacterial infection with coagulase negative staphylococci and stage of lactation on shedding of epithelial cells and infiltration of leukocytes into milk comparison among cows, goats and sheep. Vet. Immunol. Immunopathol. 147, 202-210.

Li, N., Richoux, R., Boutinaud, M., Martin, P., Gagnaire, V., 2014. Role of somatic cells on dairy processes and products: a review. Dairy Sci. Technol. 94, 517-538.

McDougall, S., Murdough, P., Pankey, W., Delaney, C., Barlow, J., Scruton, D., 2001. Relationships among somatic cell count, California mastitis test, impedance and bacteriological status of milk in goats and sheep in early lactation. Small Rumin. Res. 40, 245-254.

Nudda, A., Feligini, M., Battacone, G., Macciotta, N.P.P., Pulina, G., 2003. Effects of lactation stage, parity, $\beta$-lactoglobulin genotype and milk SCC on whey protein composition in Sarda dairy ewes. Ital. J. Anim. Sci. 2, 29-39.

Olechnowicz, J., Sobek, Z., Jaśkowski, J.M., Antosik, P., Bukowska, D., 2010. Connection of somatic cell count and milk yield as well as composition in dairy ewes. Arch. Tierz. 53, 95-100.

Pengov, A., 2001. The role of coagulase-negative Staphylococcus spp. and associated somatic cell counts in the ovine mammary gland. J. Dairy Sci. 84, 572-574.

Pirisi, A., Piredda, G., Corona, M., Pes, M., Pintus, S., Ledda, A., 2000. Influence of somatic cell count on ewe's milk composition, cheese yeld and cheese quality. Proceedings of Great Lakes Dairy Sheep Conference.

Raynal-Ljutovac, K., Pirisi, A., de Crémoux, R., Gonzalo, C., 2007. Somatic cells of goat and sheep milk analytical, sanitary, productive and technological aspects. Small Rumin. Res. 68, 126-144.

Reiad, K., Al-Azzawi, W., Al-Najjar, K., Masri, Y., Salhab, S., Abdo, Z., Saatct, M., 2010. Factors influencing the milk production of awassi sheep in a flock with the selected lines at the agricultural scientific research centre in Salamieh/Syria. Kafkas Univ. Vet. Fak. Derg. 16, 425-430.

Riggio, V., Finocchiaro, R., van Kaam, J.B.C.H.M., Portolano, B., Bovenhuis, H., 2007. Parameters for milk somatic cell score and relationships with production traits in primiparous dairy sheep. J. Dairy Sci. 90, 1998-2003.

SAS Institute Inc, 2010. Second Edition. Bases SAS ${ }^{\circ}$ 9.2.4 Procedures Guide Volumes 1, 2 , 3 , and 4 SAS Institute Inc., Cary, NC.

Silanikove, N., Merin, U., Leitner, G., 2006. Physiological role of indigenous milk enzymes: an overview of an evolving picture. Int. Dairy J. 16, 535-545.

Silanikove, N., Leitner, G., Merin, U., Prosser, C.G., 2010. Recent advances in exploiting goat's milk: quality, safety and production aspects. Small Rumin. Res. 89, 110-124.

Tolone, M., Riggio, V., Portolano, B., 2013a. Estimation of genetic and phenotypic parameters for bacteriological status of the udder somatic cell score, and milk yield in dairy sheep using a threshold animal model. Livest. Sci. 151, 134-139.

Tolone, M., Mastrangelo, S., Sardina, M.T., Portolano, B., 2013b. Effect of hairless gene polymorphism on the breeding values of milk production traits in Valle del Belice dairy sheep. Livest. Sci. 154, 60-63.

Ying, C., Yang, C.-B., Hsu, J.-T., 2002. Relationship of somatic cell count, physical, chemical and enzymatic properties to the bacterial standard plate count in different breeds of dairy goats. Asian-Australas. J. Anim. Sci. 17, 554-559. 